\title{
Petrographic and petrophysical characterisation and struc- tural function of the heritage stones in Fuwairit archaeological site (NE Qatar): implications for heritage conservation
}

\author{
${ }^{1}$ Geology Department. UTAD - University of Trás-os-Montes e Alto Douro. Quinta de Prados. 5001-801. Vila Real. Portugal; *Corresponding \\ author, E-mail: davidfreire@utad.pt \\ ${ }^{2}$ CGeo - Geoscience Center, University of Coimbra. Rua Silvino Lima. Polo II. 3030-790 Coimbra, Portugal \\ ${ }^{3}$ UCL Qatar (University College London), PO Box 25256, Georgetown Building, Education City, Doha, Qatar \\ ${ }^{4}$ Qatar Museums Authority - QMA Tower 2. PO Box 2777, Doha, Qatar
}

(Received: December 20, 2019; Revised accepted: September 9, 2020)

https://doi.org/10.18814/epiiugs/2020/0200s 12

Several types of limestones have been traditionally used for building mosques, houses and sheds in the Fuwairit archaeological site (NE Qatar). These limestones were characterised, and profiles of semi-collapsed walls examined to estimate the percentage that each building stone occupied and its structural function. Holocene beachrocks were the most used building stones. They were installed mainly as header masonry stones in the walls following coursed random rubble masonry. Pleistocene oolites were used mainly as stretcher masonry stones and Umm Bab Member of Dammam Formation (middle Eocene) as wedges and filling stones of the inner cores between the masonry wall faces. These last building stones were collected in the rocky desert, whose surface is covered by stone fragments resulting from thermal dilatation. Therefore, thermal expansion measurements were performed to investigate the breakage of the Umm Bab Member. Umm Bab Member has the lowest effective porosity and water absorption, and the highest bulk density and ultrasonic pulse velocity. This stone presents the best quality. Oolites have an intermediate quality and beachrocks have the worst quality as building stone. Historic quarries of oolites were found with abandoned stone blocks in Jebel Fuwairit fossil dunes.

\section{Introduction}

Geology, specifically the study of heritage stones, provides archaeologists with information about the types of stones used, historical quarries, degree of decay and solutions for conservation (Přikryl and Török, 2010; Zoghlami et al., 2017a; Freire-Lista and Fort, 2019; Kaur et al., 2019). Knowledge, conservation and protection of heritage stones makes it possible to develop programs contributing to the diversification of tourism and economy (Belhaj et al., 2016; Ehling, 2018; Migaszewski and Mader, 2019). Furthermore, historic quarries can in some cases guarantee the supply of stones for restorations (Grissom et al., 2018; Torabi-Kaveh et al., 2019; Garg et al., 2019; Pereira and Cárdenes, 2019).

The archaeological site of Fuwairit is located on the northeast coast of Qatar, in the municipality of Ash Shamal, approximately $90 \mathrm{~km}$ north of Doha (Fig. 1). It is a coastal town a little over a kilometre long, with the main area of ruined architecture measuring approximately $750 \mathrm{~m}$ long by $160 \mathrm{~m}$ wide, with an orientation NNW-SSE broadly parallel to the actual coast (Figs. 1-2).

Archaeological investigations by the Origins of Doha and Qatar Project indicate that the site was first significantly occupied in the 18th century, probably before the middle of the century. The site saw several abandonments and reoccupations during the $19^{\text {th }}$ century, also supported by the historical data, and at one stage it was the home town of the Al Thani dynasty, who transferred residence to Doha in the mid $19^{\text {th }}$ century. During the late $19^{\text {th }}$ and very early $20^{\text {th }}$ century it was walled, and major buildings included an unusually large congregational mosque. The majority of other buildings consisted of simple stone-built residential family compounds, with small neighbourhood mosques, and a large sheikhly compound found close to the centre of the site, dating to the early $20^{\text {th }}$ century (older sheikhly compounds and forts were likely present but remain undiscovered). Its final occupation, by members of the Bu Kuwara tribe, took place in the early $20^{\text {th }}$ century, ending in the early 1930s. This occupation provided the core of collapsed buildings in the centre of the site. Frequent episodes of rebuilding and stonerobbing have heavily disturbed the building remains of earlier occupations beneath and surrounding the final occupation phase. A small resettlement later took place to the south of the site, which from the 1950s onwards expanded into today's village of Fuwairit. Throughout its occupation from the $18^{\text {th }}$ to the early $20^{\text {th }}$ century it can be characterised as a small pearl-fishing town.

The aims of this paper are to characterise the building stones preserved in the archaeological site of Fuwairit, to know where and which ones were most frequently used, to know the intrinsic causes of their decay and to locate their historic quarries. 


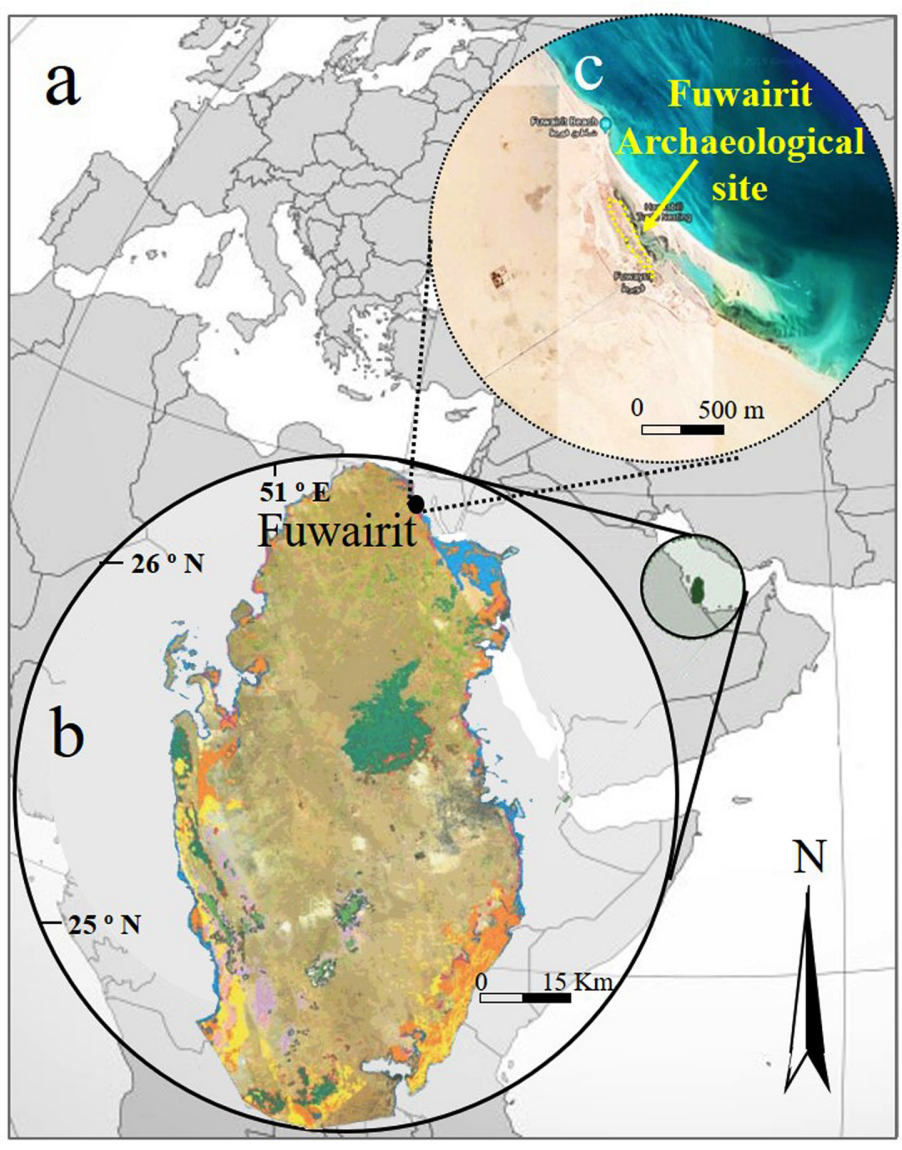

\section{HOLOCENE/QUATERNARY}

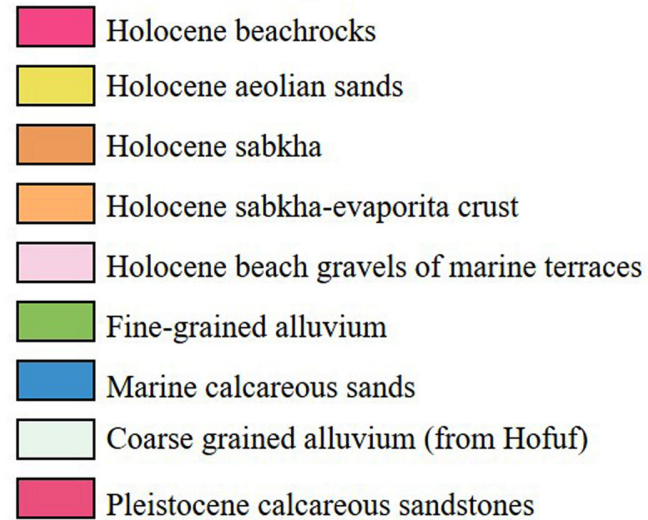

CENOZOIC

Miocene/Pliocene. Hofuf Formation

Miocene. Upper Dam Formation

Miocene. Lower Dam Formation

Eocene. Upper Dammam Formation

(Abaruq member)

Eocene. Upper Dammam Formation (Umm Bab member prev. Simisima)

Eocene. Lower Dammam Formation

Eocene. Rus Formation

Eocene. Rus Formation (Gypsum)

Eocene. Umm er Radhume Formation

Figure 1. (a) Location map of Fuwairit archaeological site (b) Geological map of Qatar (Source: Qatar Geological Society), (c) Google Earth map of Fuwairit area (Data: SIO, NOAA, US Navy, NGA, GEBCO. Image: Landsat/Copernicus).

The middle Eocene Damman Formation is the main source of traditional building stone in Qatar (Jassim al-Kholaifi, 2006; Karagkounis, 2016). However, younger limestones (Pleistocene-Holocene) of coastal origin, and less consolidated than the Dammam Formation, were also used as building stones in the vernacular buildings of Qatar (FreireLista et al., 2019).

\section{Geological Settings}

The archaeological site of Fuwairit is on a Holocene fossil chenier plain, between aligned Pleistocene fossil dunes, the main outcrop of which is called Jebel Fuwairit. These consolidated coastal oolitic ridges were deposited on the Upper Dammam Formation. The fossil dunes are close and pseudo-parallel to the shoreline. On the landward side, this oolitic ridge gives way to supratidal flats, sabkhas, and the rocky desert (hamada) with fractured stones of the Umm Bab Member of the Dammam Formation (middle Eocene carbonate deposits).

The Dammam Formation represents marine conditions in most eastern parts of the Arabian Gulf. Fluctuations in sea level were recognised in it, showing at least three transgressive/regressive cycles. A warm shallow marine environment was predominant as indicated by extensive dolomitisation and the presence of alveolines, linderines and nummulites (Al-Saad, 2005). The Dammam Formation is subdivided into four members (from oldest to youngest): Midra Shale, a compact claystone; Dukhan, a hard limestone; Umm Bab, a dolomitic limestone and Abaruq, a marly dolomitic limestone (Sadooni and Al-Saad, 2012).

The Umm Bab Member outcrops in the hamada of Fuwairit. This member was deposited in a shallow marine environment, after which the sea levels dropped and exposed the rocks to weathering during the Oligocene. Wet climatic conditions during the Pleistocene initiated the development of dissolution features from millimetres to metres long. Therefore, an unconformity exists between Eocene and Pleistocene.

The surface of Qatar has been exposed since the end of the last interglacial period (ca. 119,000 BP). The lower part of Jebel Fuwairit is made up of marine carbonate-sand bars, the upper part shows a change toward wind-blown dune deposits of oolites. They were deposited as coastal dunes adjacent to beaches where abundant calcareous sand was available. The accumulation of these sediments is related to climatic changes and fluctuations in sea level. Wind sediments were deposited during high stand of the sea-level in the Sangamonian (75,000 $125,000 \mathrm{BP}$ ) (Williams and Walkden, 2002). The oolites are characterised by medium-scale cross bedding. Sets of cross-beds vary in thickness from meters to centimetres and generally pinch out over lateral distances of tens of meters. Their strata show rhizocretions (fossil root systems that have been encased in mineral matter), burrows (fossil hole or tunnel excavated by an animal) and desiccation cracks filled with mud, suggesting an alternation of flooding and stable periods, 

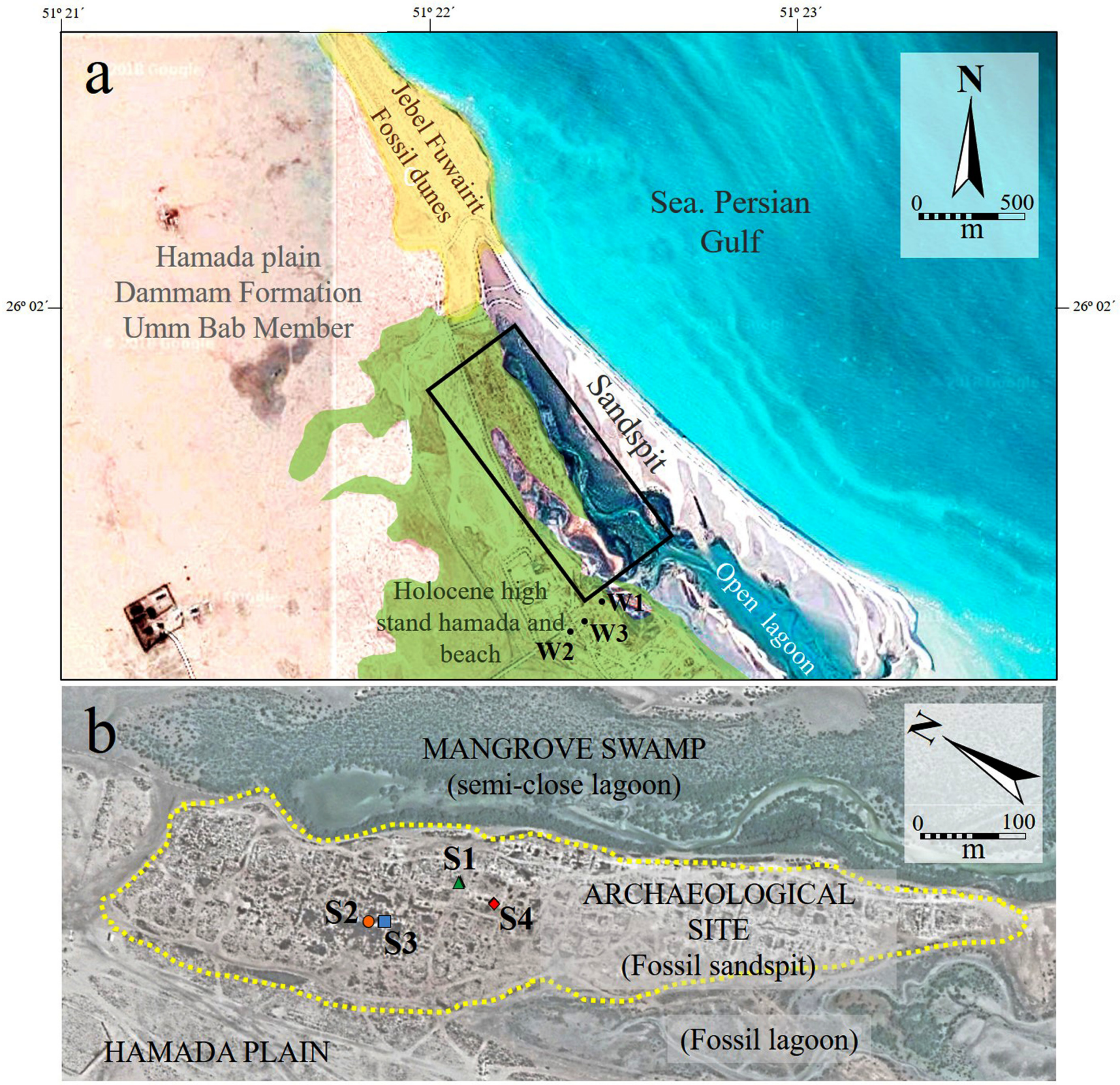

Figure 2. (a) Google Earth map of Fuwairit area. The location of the longitudinal and transverse walls sections is indicated, (b) Red top box detail. The perimeter of the remains of the ancient city is marked with a yellow dotted line. The location of the places where the masonry samples have been collected is indicated (Data: SIO, NOAA, US Navy, NGA, GEBCO. Image: Landsat/Copernicus). Note: This figure has its own color code, independent from that of figure 1.

although the water that has percolated through the dunes has not been enough to dissolve all the aragonite. The dunes were stabilised by cementation of ooid grainstones and vegetation.

Pleistocene pluvial events and eustatic sea-level changes have played an essential role in the evolution of Fuwairit area. A river system with approximate SW-NE direction cut and eroded part of the dunes ridge, where the archaeological site would later be established. Changes in sea level produced throughout the Holocene configure the current geomorphology of the area. This period began approximately 11,700 years ago, when temperatures ameliorated as the sea level rose (Macumber, 2011).
In early Holocene times, coastal embayments containing little sediment and with wide entrances that were open to the ocean, and cliffs of Eocene limestones and dolomites, drew a tortuous coastline on the east side of Qatar. After stabilisation of the present sea level, fine grained, carbonate sediment and dolomite out-wash from the land began to fill and regularise the coastal embayments (Cavalcante et al., 2016). Concurrent longshore transport of recent coarse-grained carbonates from the north created "chenier" beaches with hook-shaped spits at their southern ends, which gave added protection to these prerecent embayments. Contemporaneously, additional cheniers and spits were forming seawards of the older one creating quiet water embayments. During this 


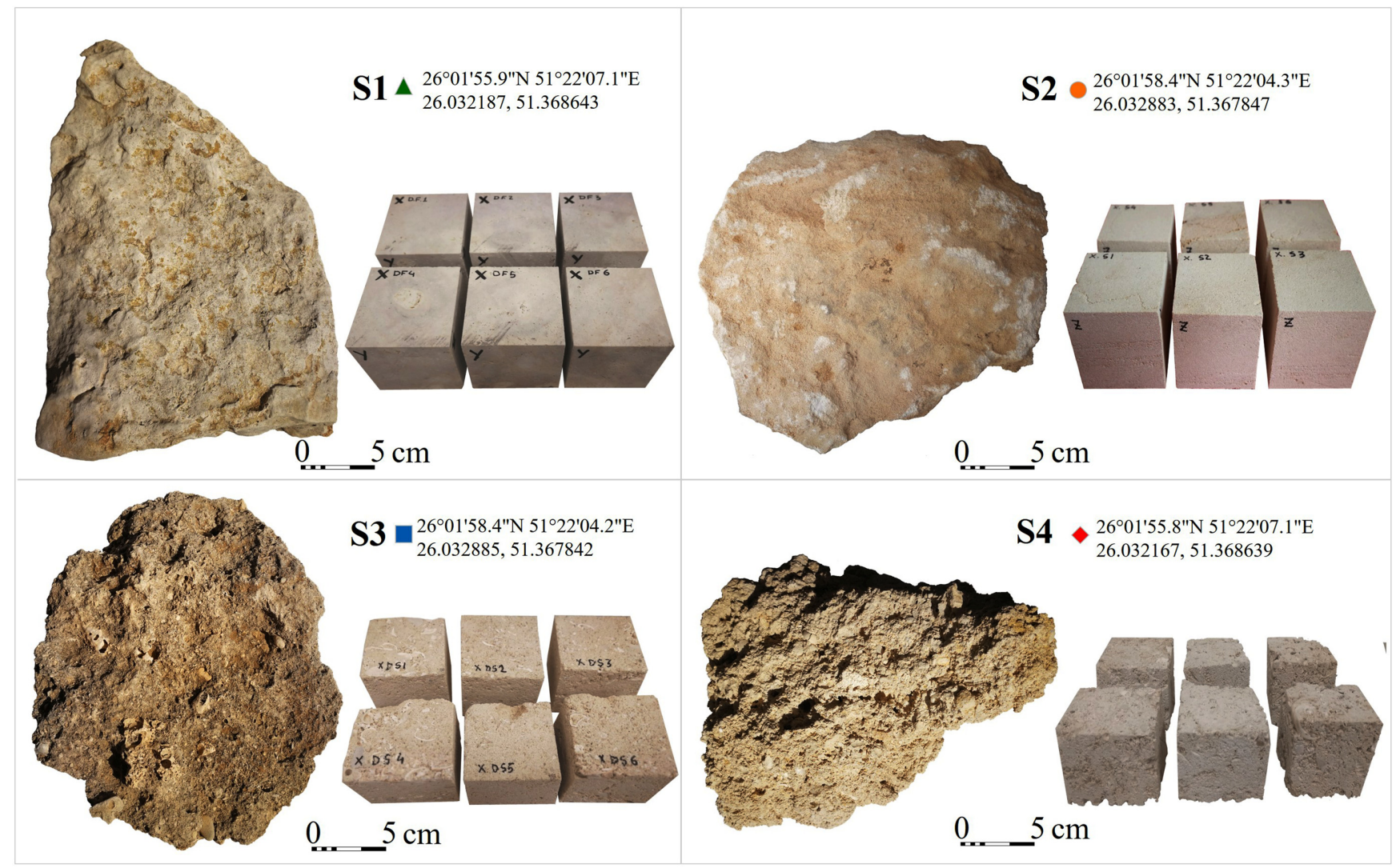

Figure 3. Samples of masonry stones collected at Fuwairit archaeological site and six cubes obtained from each of them for petrophysical analysis.

five to six thousand-year period, a tidal channel system developed on the flats behind and between successive cheniers and spits that straightened the coast of Fuwairit. Thus, Fuwairit archaeological site is over a distinct body of sediment differing notably from the sands and coral reefs at present accumulating a short distance off-shore. It is a system of coastal accretion by carbonate sediment influenced by longshore transport.

\section{Methodology}

Petrographic, mineralogical and petrophysical analysis provide quantitative values of parameters directly related to the quality and durability of building stones (Freire-Lista et al., 2015, 2016; Murru et al., 2018; Zalooli et al., 2020). These parameters have been measured and compared to establish the quality and durability of four building stones from Fuwairit archaeological site.

\section{Sampling of Building Stones and in situ Analysis}

After studying the geology of the area and carry out archaeological surveys, four main types of masonry stones were sampled of the Fuwairit archaeological site (Figs. 2-4). This is composed of small mounds of ruins, stone fragments and disaggregated building materials. S1: whitish-beige, compact, massive and with fine-grain size, which was identified as Eocene limestone (Umm Bab Member of Dammam Formation);
S2: homogeneous medium- to coarse-grain size, yellowish colour and sets of cross-beds evident to the naked eye; S3: yellowish with fossils, especially shells of bivalves and gastropods. Bioclasts size ranges from millimetres to centimetres, with wide pore size distribution and high moldic porosity. $\mathrm{S} 2$ and $\mathrm{S} 3$ were identified as being from different strata of the fossil dunes of Jebel Fuwairit. S4: whitish with fossils, especially shells of bivalves and gastropods. Bioclasts size ranges from millimetres to centimetres in a muddy matrix, poorly consolidated and with high porosity. It was identified as Holocene "beachrock" found under the foundations of buildings.

These four stones types found in the Fuwairit ruins are as the stone types found in the ruins of three house walls adjacent to the archaeological site. These walls have a similar fabric to those of the ruins of the archaeological site.

The percentage of each type of masonry stones used in three collapsed walls (W1, W2 and W3) of houses in Fuwairit village, near the archaeological site (Fig. 2), was quantified by longitudinal and transverse sections. In situ mapping was undertaken to analyse of the wall masonries. The type of masonry stone identified in the walls was marked on printed photographs, distinguishing between Eocene limestone, Pleistocene oolites and Holocene beachrocks. The percentage of masonry stone in each wall was calculated (see, Fig. 5). In addition, the structural function of each masonry stone type was characterised as follows: Header: a stone which has its longest dimension built into the thickness of the wall to improve bonding and strength; Stretcher: a stone which connected both faces of the masonry wall; Wedges: small 

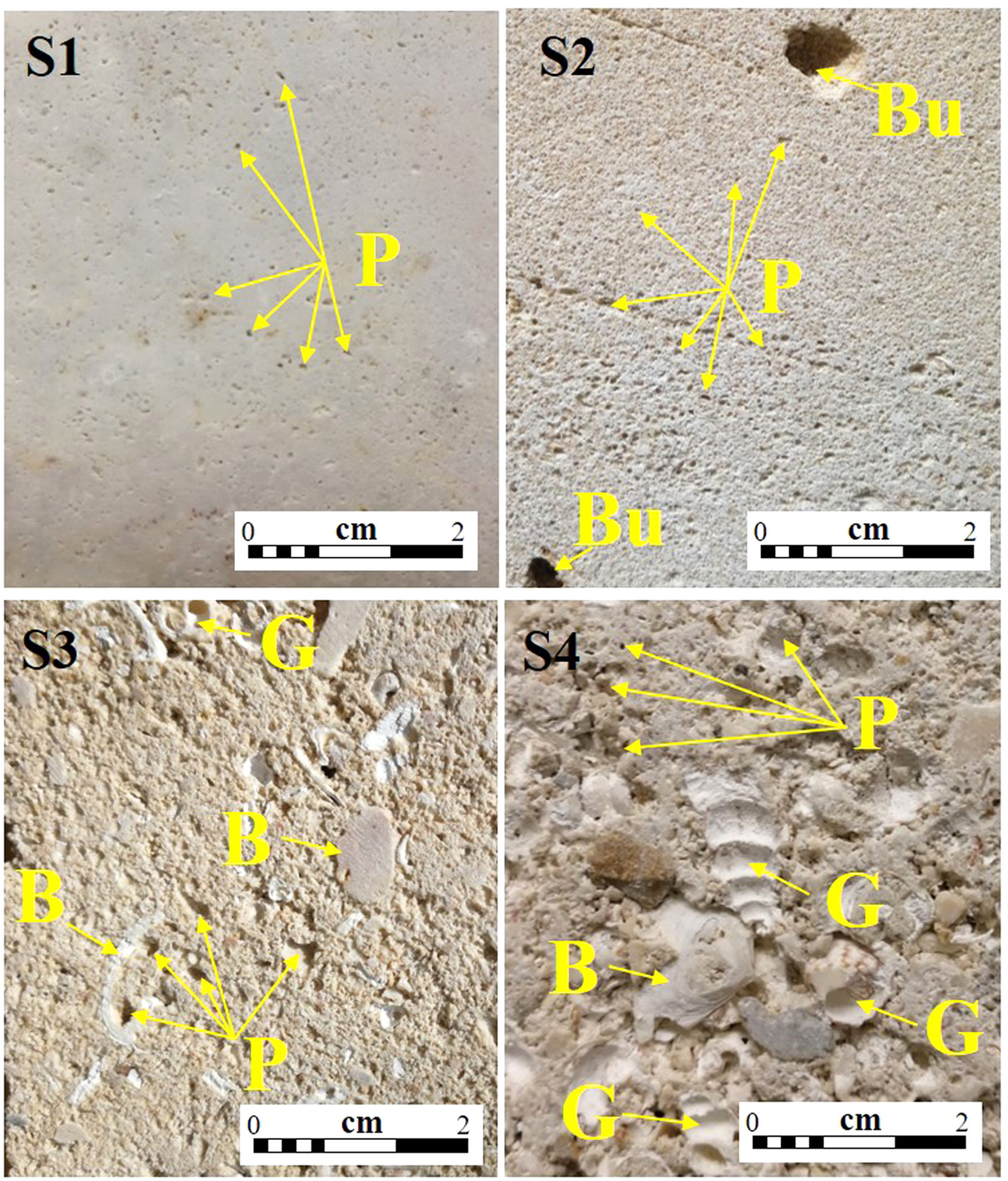

Figure 4. Naked-eye view of main building stone types used in Fuwairit archaeological site (B: bivalve; Bu: burrow; G: gastropod; P: pore).

stones that serve to level stones for the stones row be aligned; and Filling Stones: stones that are placed in the inner core between both faces of the masonry wall (Barroso et al., 2018).

Seven cubic $(5 \times 5 \times 5 \pm 0.5 \mathrm{~cm})$ specimens were cut from $\mathrm{S} 1, \mathrm{~S} 2$, S3 and S4 (Fig. 3).

\section{Petrographic Microscopy (PM)}

Two thin sections were made from each building stone, one oriented perpendicular to and one parallel to the stratification. They were observed under a polarisation microscope Leica DM 4500 P, equipped with a digital FireWire Camera Leica DFC 290 HD that worked with the Leica application suite software LAS 4.

\section{X-Ray Diffraction (XRD)}

A fragment of each building stone was pulverised to $50 \mu \mathrm{m}$ to use at a MiniFlex benchtop X-ray diffractometer operated at $40 \mathrm{KV}$ and $30 \mathrm{~mA}$. The measurements were performed in a range between 2 and 68 degrees with an interval of 0.02 and $2 \mathrm{~min}$ in continuous mode, and they were processed with Miniflex Guiadance and PDXL 2 Rigaku diffraction software.

\section{Effective Porosity (Pe), Water Absorption and Bulk Den- $\operatorname{sity}(\rho b)$}

Six cubic samples of S1, S2, S3 and S4 were tested for effective poros- 
ity $(P e)$, water absorption capacity and bulk density $(\rho b)$ according UNEEN 1936: 2007 following these equations:

$$
\begin{aligned}
& \operatorname{Pe}(\%)=[(\mathrm{Ws}-\mathrm{Wd}) /(\mathrm{Ws}-\mathrm{Wh})] \times 100 \\
& \text { Water absorption }(\%)=[(\mathrm{Ws}-\mathrm{Wd}) /(\mathrm{Wd})] \times 100 \\
& \rho b\left(\mathrm{Kg} / \mathrm{m}^{3}\right)=[(\mathrm{Wd}) /(\mathrm{Ws}-\mathrm{Wh})] \times 100
\end{aligned}
$$

Where Wd is the weight of the dry specimens (after oven-drying at $70{ }^{\circ} \mathrm{C}$ and desiccation for $30 \mathrm{~min}$ ). Ws is the weight of $24 \mathrm{~h}$ water-saturated sample, and Wh is the weight of the sample submerged in water.

\section{Mercury Intrusion Porosimetry (MIP)}

The micropore size distribution was measured by mercury intrusion porosimetry (MIP; Pascal 140 and Pascal 440 from Thermo Scientific) using irregular S1, S2, S3 and S4 samples (ca. $1.0 \mathrm{~g}$ ). The analysis was run on samples oven-dried to a constant weight at $70{ }^{\circ} \mathrm{C}$. Pressures up to $400 \mathrm{MPa}$ were used to evaluate the pore radii measured at around $0.005 \mu \mathrm{m}$.

\section{Ultrasonic Pulse Velocity $\left(V_{p}\right)$}

Ultrasonic pulse velocities $\left(\mathrm{V}_{\mathrm{p}}\right)$ were measured on each of the six cubes of each building stone in the three orthogonal directions, using the mean of four consecutive measurements of each face of the cube as the accepted value.

$\mathrm{V}_{\mathrm{p}}$ was taken with CNS Electronics PUNDIT equipment (precision: $\pm 0.1 \mu \mathrm{s}$ ) following UNE-EN, 14579, 2007. The $1 \mathrm{MHz}$ transducers (11.82 $\mathrm{mm}$ in diameter) were affixed to the surface with a carboxymethyl cellulose paste and water to enhance the transducer-stone contact. $V_{p}$ is a portable non-destructive technique, with an analytical sensitivity able to detect petrophysical changes not currently visible on the surface of the stones (Martínez-Martínez et al., 2008; Zoghlami et al., 2017b; Kravcov and Shibaev, 2019).

\section{Colour}

After oven-drying at $70{ }^{\circ} \mathrm{C}$ to a constant weight, 20 colour measurements were taken in each stone, and the mean was calculated. Afterwards each stone was submerged in water for an hour and 20 measurements of the colour were taken again in the wet stones. The colour was assessed with a X-Rite colorimeter (model 964 ), with $45^{\circ} / 0^{\circ}$ geometry and specular component included, D65 illuminant and $8 \mathrm{~mm}$ aperture. Colour was expressed using the three chromatic coordinates of CIE-L*a*b* system (Sanmartín et al., 2011). The colour difference $\left(\Delta \mathrm{E}^{*}\right)$ between the dry and wet state was calculated for each stone.

\section{Thermal and Hydric Dilatometry}

Thermal and hydric dilatation measurements were taken in S1 specimen with a length of $50 \mathrm{~mm}$ and a diameter of $15 \mathrm{~mm}$, with a temperature range of $20-90^{\circ} \mathrm{C}$, using a pushrod dilatometer (for details see, Koch and Siegesmund, 2004). Heating and cooling were performed with a velocity of $1{ }^{\circ} \mathrm{C} / \mathrm{min}$ and the maximum and minimum temperatures were held for $6 \mathrm{~h}$. This cycle was implemented 3 times and the results were used to describe the thermal dilatation behaviour of $\mathrm{S} 1$. The thermal dilatation coefficient $\alpha\left(10^{-6} \mathrm{~K}^{-1}\right)$ was calculated as the ratio between the length change of the samples $(\Delta \mathrm{L})$ and the original sample length (L) multiplied by the temperature interval (Siegesmund and Dürrast, 2014).

\section{Results}

\section{In-situ Measurements and Observations}

Rubble masonry of undressed and rough stone blocks was used for the vernacular buildings of Fuwairit at both the archaeological site and at the mid- $20^{\text {th }}$ century village. Semi-collapsed architecture at the village shows that larger stones were laid down first and the spaces between them were filled up with chips of stones, debris and local earth mortar (Fig. 5). W1, W2 and W3 walls are formed by coursed random rubble masonry between two skins of walling made of unshaped stones of different sizes and shapes arranged in courses of similar height, approximately 30 to $40 \mathrm{~cm}$ long (Fig. 5). At the inner core, houses walls showed a poor infill of debris, with a considerable percentage of voids and insufficient interlocking.

W1 was built with $13.4 \%$ of Eocene stones (S1), 3.9\% of Pleistocene stones (S2 and S3) and $82.7 \%$ of Holocene stones (S4). W2 was built with $19.0 \%$ of Eocene stones, $4.7 \%$ of Pleistocene stones and $86.3 \%$ of Holocene stones. W3 was built with $13.4 \%$ of Eocene stones, $5.1 \%$ of Pleistocene stones and $81.5 \%$ of Holocene stones.

$\mathrm{S} 4$ forms the largest stones, present as header stones. S2 and S3 were usually placed as stretcher stones. $\mathrm{S} 1$ was used as wedges to fit the masonry stones, and as filling debris of the inner core between both faces.

\section{Petrographic Microscopy (PM)}

$\mathrm{S} 1$ is a compact dolomite with micritic cement. The grain size distribution is homogeneous. It has a high degree of compaction and low porosity, no detrital components are observed, and there are dissolution cavities and some irregular veins cemented by calcite. Various crystalline calcite growths of different episodes or cementation phases are observed.

Numerous inclusions give dolomite crystals a cloudy appearance. However, some dolomite crystals show relics of the original calcite in their nuclei. Calcite crystals precipitate into secondary pores such as biomolds, vugs and veils. The nuclei of some other thick dolomite crystals are leached and leave micropores. Skeletal fragments of echinoids and foraminifera are observed.

This stone is classified as a fossiliferous biomicrite (Folk, 1962) and as a wackestone (Dunham, 1962) (Fig. 6a, and b).

$\mathrm{S} 2$ is an ooid limestone characterised by medium- scale crossbedding and a vuggy fabric with ophimorpha burrows and cemented roots. It shows homogeneous granulometry. Ooid grains are well sorted and medium- to coarse-grained, with sparse fossils debris as echinoid spines. It is crossbedding, almost devoid of skeletal components and consists almost exclusively of ooids and coated grains. Ooids display concentric laminae. The nuclei of ooids are mostly carbonates, but there are also quartz nuclei. In addition to normal ooids with composite coatings ( $0.1 \mathrm{~mm}$ average thickness). The ooid cortices consist of alternating clear thick lamellae and dark thin micritic laminae made up of minute 

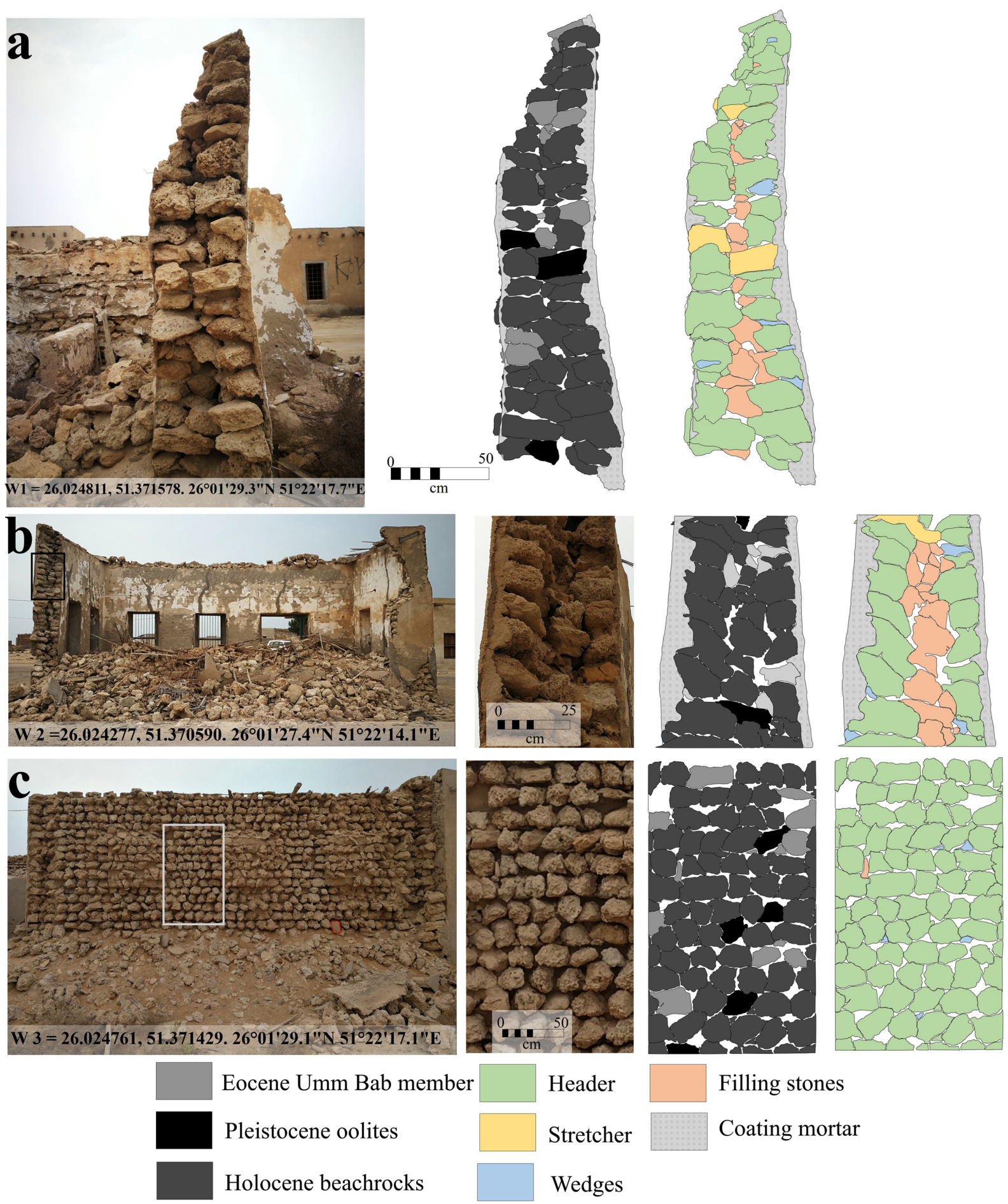

Header

Stretcher

Filling stones

Coating mortar

Wedges

Figure 5. Coursed rubble stone masonry walls of vernacular houses close to Fuwairit archaeological site (i.e., in Fuwairit village, 1950s1970s). (a) Collapsed house wall and cross-sections analysis of the wall masonry stones, (b) General view of the ruins of a house and crosssections analysis of the masonry stones, (c) Longitudinal-section analysis of a house wall with collapsed interior leaf.

grains. Cortices and/or the nuclei of many ooids have been dissolved leaving oo-moldic porosity. The molds are sharply defined, commonly surrounded by micrite rims and in some cases partially filled by calcite cements. The interparticle porosity is occluded by calcite cements. The equant spar of calcite is the volumetrically most important cement. These cements were precipitated as isopachous rims, filling interparticle, intraparticle and oo-moldic porosity. The calcite cement surrounds the ooids grains and reduces more substantially the primary as well as the secondary porosity.

This stone is classified as an oosparite (Folk, 1962) and as a grainstone (Dunham, 1962) (Fig. 6c, and d).

$\mathrm{S} 3$ has a greater distribution of bioclasts and grain size than S2 and is an ooid limestone. Ooid grains are sorted, and they are medium- to coarse-grained, with fossils debris as echinoid spines, bivalves, corals, 


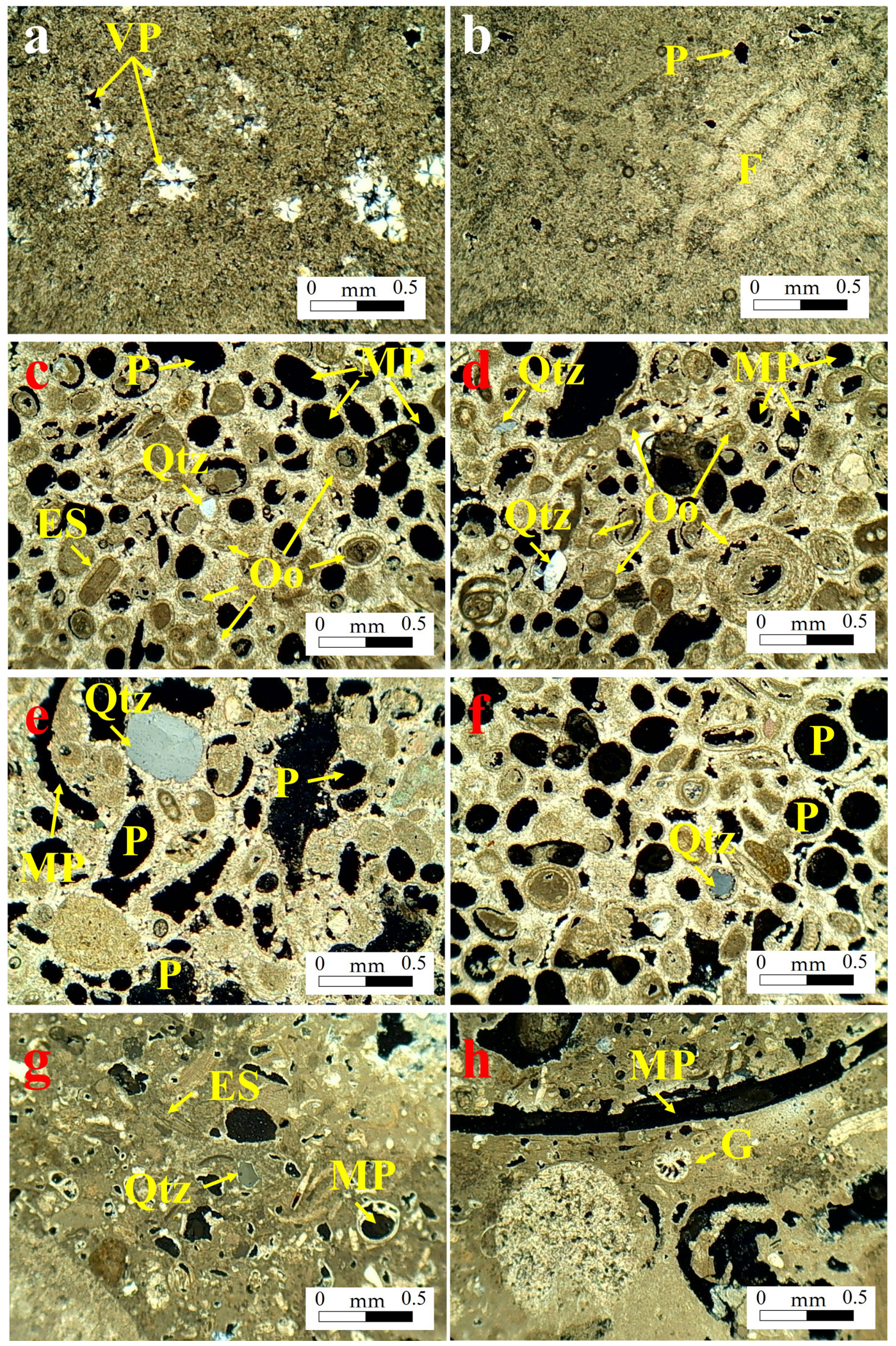

Figure 6. Crossed Nicol microscopic images of the four masonry stones types. a-b: sample S1; c-d: sample S2; e-f: sample S3; g-h: sample S4. (B: Bivalve; ES: echinoid spines; F: foraminifer; G: gastropod; MP: moldic pore; Qzt: quartz; Oo: oolites; P: pore; VP: vuggy porosity).

green algae and pebbles with a diameter that can be greater than $1 \mathrm{~cm}$ (Fig. 4).

Ooids display concentric laminae (Fig. 6c and d). Their nuclei are mostly carbonates, but there are also quartz nuclei. In addition to normal ooids with composite coatings ( $0.1 \mathrm{~mm}$ average thickness), there are superficial ooids having only one coating. Ooids have relatively thin cor- 
tices compared to the size of their nuclei. The composition of the ooid grains varies from aragonite, their primary mineralogy, to complete replacement by calcite. Cortices and/or the nuclei of many ooids have been dissolved. It is very porous mostly oo-moldic, bio-moldic and burrows, with some interparticle, microporosity in clasts. The molds are sharply defined, commonly surrounded by micrite rims and in some cases partially filled by calcite cements. The interparticle porosity is occluded by calcite cements. Components show little cement by equant blocky spar and a few micritic envelops. The equant spar of calcite is the volumetrically most important cement in S3. These cements were precipitated as isopachous rims, filling pores.

This stone is classified as an oosparite (Folk, 1962) and as a grainstone (Dunham, 1962) (Fig. 6e and f).

S4 is poorly sorted and shows heterogeneous granulometry. It is characterised by heterogeneous and random fossils debris of echinoid spines, bivalves, corals, and gastropods with a diameter that can be greater than $3 \mathrm{~cm}$. It has extraclasts (small clasts of quartz, fossiliferous limestone and dolomite). It is mainly composed of poorly consolidated mud, and it is poorly cemented. The dominant porosity is intragranular and bio-moldic, vuggy fabric (Fig. 4). It is classified as a biomicrite (Folk, 1962) and as a packstone (Dunham, 1962) (Fig. 6g and h).

\section{X-Ray Diffraction (XRD)}

$\mathrm{S} 1$ is composed of dolomite (main mineral), calcite, and ankerite; $\mathrm{S} 2$ is composed of calcite and aragonite in low proportion; $\mathrm{S} 3$ is composed of calcite and S4 is composed of calcite, and dolomite and
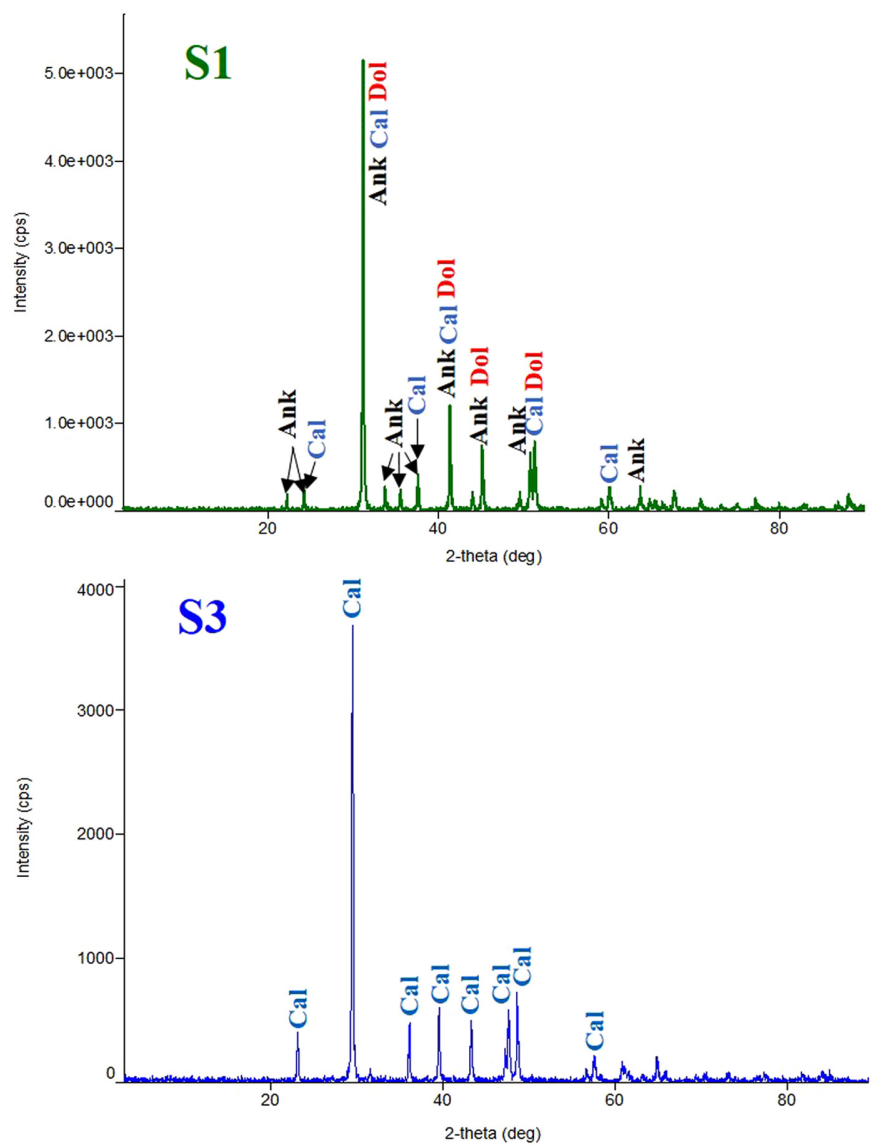

quartz in low proportion (Fig. 7).

\section{Effective Porosity (Pe), Water Absorption and Bulk Den- $\operatorname{sity}(\rho b)$}

The values of $P e$, water absorption and $\rho b$ were different in the four samples. Thus, $\mathrm{S} 1$ showed the lowest $P e$. Water absorption showed a similar distribution, $\mathrm{S} 1$ showed the lowest value. $\rho b$ was clearly different for $\mathrm{S} 1$, with greater value (Table 1).

\section{Mercury Intrusion Porosimetry (MIP)}

S1 presented the lowest MIP of all analysed samples (7.77\%), and its micropore size distribution was mainly concentrated on radius sizes between 0.001 and $0.01 \mu \mathrm{m}$. S2, S3 and S4 presented a similar value of MIP. Although their radius size distribution varied from one sample to another one. Sample S2 showed an MIP of $22.29 \%$; the highest percentage of micropores had a radius of around $1 \mu \mathrm{m}$. S3 had the highest MIP of the three samples analysed with $23.10 \%$. Its pores were concentrated in a range of radius size between 10 and $100 \mu \mathrm{m}$, that is, macropores. Sample S4 showed a MIP of $21.96 \%$. Fig. 8 shows MIP radius size distribution of the four samples.

\section{Ultrasonic Pulse Velocity $\left(V_{p}\right)$}

The building stones have shown wide-ranging $V_{p}$ values, indicating their different quality. $S 1$ has had the highest $V_{p}$. S2 showed an inter-
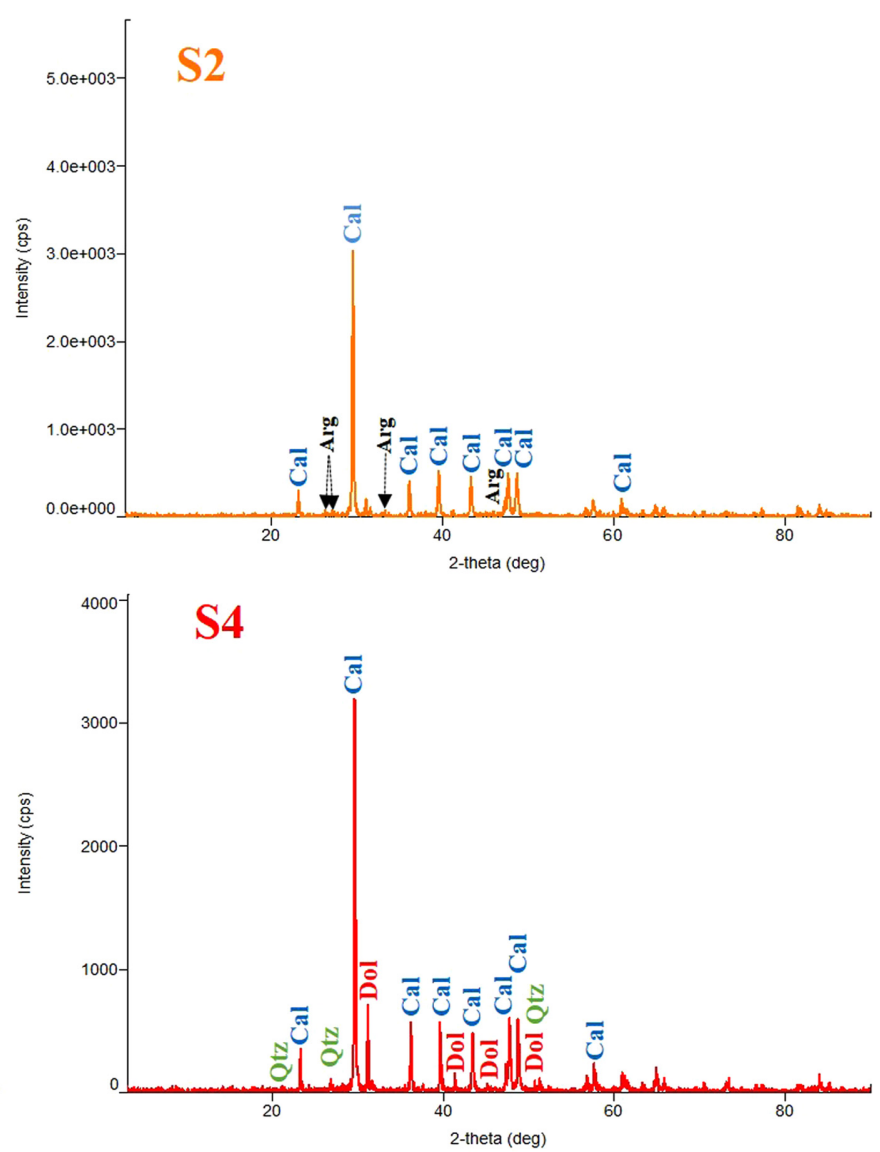

Figure 7. XRD results. Ank: ankerite; Arg: aragonite; Cal: calcite; Dol: dolomite; Qtz: quartz. 
Table 1. Mean values of effective porosity (Pe), water absorption, bulk density ( $\rho b)$ and ultrasound pulse velocity $\left(V_{p}\right)$ of the analysed building stones

\begin{tabular}{ccccc}
\hline \hline & Pe (\%) & Water absorption (\%) & $\rho b\left(\mathrm{~kg} / \mathrm{m}^{3}\right)$ & $\mathrm{V}_{\mathrm{p}}(\mathrm{m} / \mathrm{s})$ \\
\hline S1 & $2.0 \pm 0.2$ & $0.8 \pm 0.1$ & $2537.0 \pm 16$ & $5912 \pm 201$ \\
S2 & $8.1 \pm 0.8$ & $4.6 \pm 0.5$ & $1752.7 \pm 19$ & $3651 \pm 102$ \\
S3 & $22.1 \pm 1.3$ & $13.3 \pm 1.2$ & $1666.3 \pm 47$ & $2840 \pm 190$ \\
S4 & $20.1 \pm 1.0$ & $11.6 \pm 0.6$ & $1729.8 \pm 15$ & $2893 \pm 169$ \\
\hline
\end{tabular}
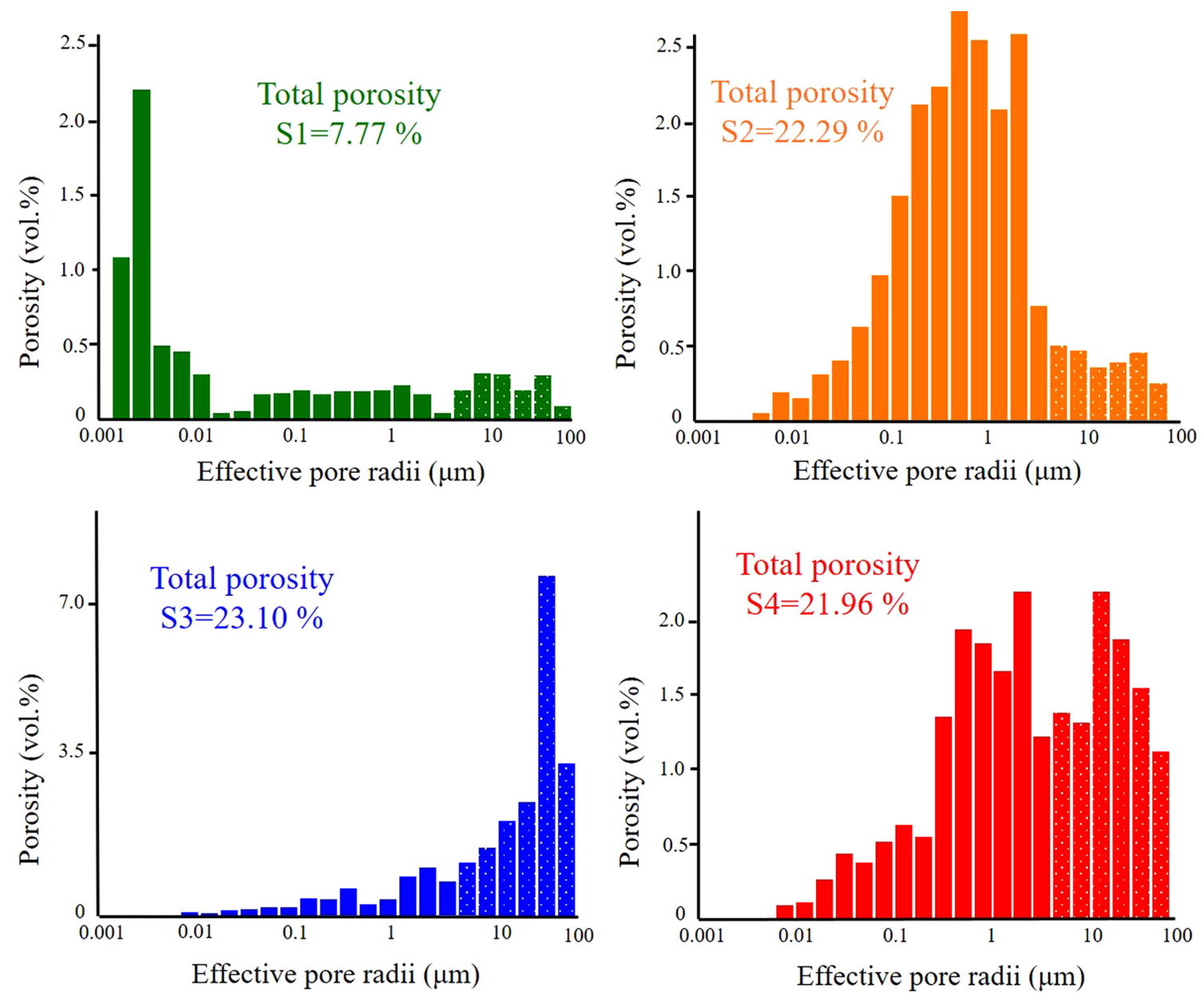

Figure 8. Pore size distribution graphs for samples S1, S2, S3 and S4.

Table 2. Mean values of colour parameters (dry and wet state) of the analysed building stones

\begin{tabular}{|c|c|c|c|c|c|c|c|c|c|c|}
\hline & \multicolumn{3}{|c|}{ Dry color } & \multicolumn{3}{|c|}{ Wet color } & \multicolumn{4}{|c|}{$\Delta$} \\
\hline & $\mathrm{L}^{*}$ & $a^{*}$ & $\mathrm{~b}^{*}$ & $\mathrm{~L}^{*}$ & $a^{*}$ & $\mathrm{~b}^{*}$ & $\Delta \mathrm{L}^{*}$ & $\Delta \mathrm{a}^{*}$ & $\Delta \mathrm{b}^{*}$ & $\Delta \mathrm{E}^{*}$ \\
\hline S1 & $83.0 \pm 5.8$ & $0.6 \pm 0.1$ & $4.3 \pm 1.2$ & $77.8 \pm 2.8$ & $1.3 \pm 0.3$ & $7.5 \pm 1.4$ & 5.2 & -0.7 & -3.2 & 6.2 \\
\hline S2 & $82.3 \pm 0.8$ & $2.3 \pm 0.2$ & $11.8 \pm 1.1$ & $74.2 \pm 1.0$ & $3.4 \pm 0.3$ & $16.3 \pm 0.6$ & 8.0 & -1.1 & -4.5 & 9.3 \\
\hline S3 & $78.9 \pm 2.0$ & $3.4 \pm 1.1$ & $15.2 \pm 1.5$ & $73.1 \pm 1.6$ & $4.5 \pm 0.3$ & $18.5 \pm 1.8$ & 5.9 & -1.1 & -3.3 & 6.8 \\
\hline S4 & $82.5 \pm 1.8$ & $1.1 \pm 0.5$ & $10.0 \pm 0.9$ & $75.5 \pm 3.3$ & $1.5 \pm 0.4$ & $12.4 \pm 1.5$ & 7.0 & -0.4 & -2.4 & 7.4 \\
\hline
\end{tabular}

Foot notes: $\mathrm{L}^{*}$ : lightness; $\mathrm{a}^{*}$ : red-green value; $\mathrm{b}^{*}$ : blue-yellow value; $\Delta \mathrm{E}^{*}$ : colour difference.

mediate value of $V_{p}$, and $S 3$ and $S 4$ have shown the lowest $V_{p}$ values (see Table 1).

\section{Colour}

All building stones showed light colours and high luminosity $\left(\mathrm{L}^{*}\right)$.
$\mathrm{L}^{*}$ was reduced slightly in the wet state. S1 and S4 were the whitest, both in dry and wet state. S2 and S3 were more yellow than S1 and $\mathrm{S} 4$, both in dry and wet state. No sample has experienced a considerable $\Delta \mathrm{E}^{*}$ between the dry and the wet state, $\mathrm{S} 2$ showed the highest $\Delta \mathrm{E}^{*}$ value (see, Table 2 and Fig. 9). 


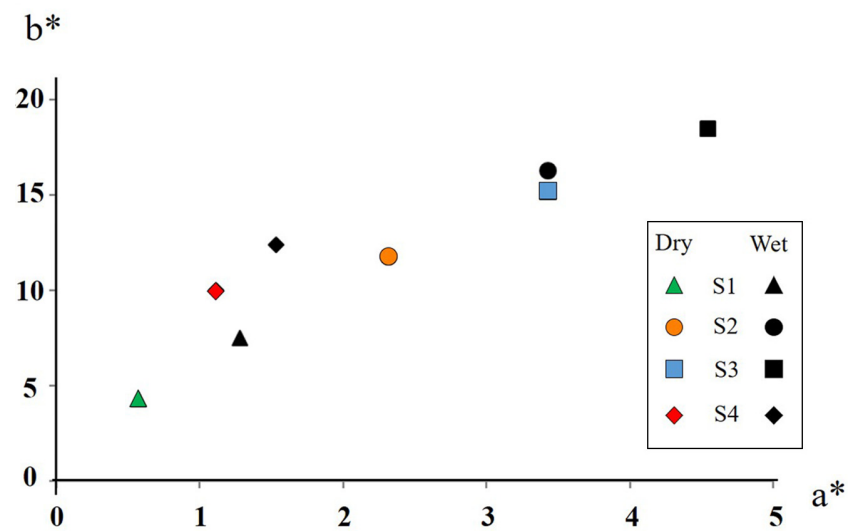

Figure 9. Parameters $a *$ and $b$ * of samples $S 1, S 2, S 3$ and $S 4$ in dry and wet state.

\section{Thermal and Hydric Dilatometry}

Fig. 10 shows the relative length change $(\varepsilon(\mathrm{mm} / \mathrm{m}))$ as a function of for S1. The behaviour is similar in both dry and wet conditions, with a continuous length change and without residual strain (Strohmeyer, 2003; Gräf et al., 2013; Menningen et al., 2018). The mean values of the thermal dilatation coefficient, $\alpha$, range from $9.68 \times 10^{-6} \mathrm{~K}^{-1}$ in dry condition to $10.84 \times 10^{-6} \mathrm{~K}^{-1}$ in wet condition (Table 3 ).

\section{Discussion and Archaeological Considerations}

S1 has the best hydric properties: low $P e$ and microporosity, that produces low water absorption and high values of $\mathrm{V}_{\mathrm{p}}(>5,900 \mathrm{~m} / \mathrm{s})$. $\mathrm{S} 1$ is a high-quality building stone when compared to others $\mathrm{V}_{\mathrm{p}}$ values of widely used building stones (Fort et al., 2013; Freire-Lista and Fort, 2019).

Its thermal dilatation values shown in Table 3 (mean 9.68 and
Table 3. Values of thermal dilatation coefficient $\alpha\left(10^{-6} \mathrm{~K}^{-1}\right)$ in dry and wet conditions

\begin{tabular}{ccc}
\hline \hline \multirow{2}{*}{ Cycle } & Dry & Wet \\
\cline { 2 - 3 } & $\alpha\left(10^{-6} \mathrm{~K}^{-1}\right)$ & $\alpha\left(10^{-6} \mathrm{~K}^{-1}\right)$ \\
\hline 1 & 10.49 & 11.12 \\
2 & 9.27 & 10.29 \\
3 & 9.3 & 11.12 \\
Mean & 9.68 & 10.84 \\
\hline
\end{tabular}

$10.29 \times 10^{-6} \mathrm{~K}^{-1}$ for dry and wet conditions respectively) are more than twice the mean value of other carbonate dimension stones (Leite and Moura, 2013). Vendrell-Saz et al. (1996) mention values between $1.5 \times 10^{-6}{ }^{\circ} \mathrm{C}^{-1}$ and $4 \times 10^{-6}{ }^{\circ} \mathrm{C}^{-1}$ for a limestone building stone. High values of $\alpha$, together with high temperatures that reach the surface stones of the hamada and the cooling due to rain will produce a rapid surface contraction that causes the fragmentation of the Umm Bab Member. Texture, grain size and thermal dilatation of stones are the main factors that determine the rate of thermal decay due to, among other causes, physical-chemical processes that act to break bonds at cracks tips (Rong et al., 2018; Al-Omari et al., 2019; Jin et al., 2019; Peng et al., 2019; Shen et al., 2019). Cracking proceeds even when only extremely low stresses are applied to the stone (akin to very small pulling forces). These stresses can be due to occurrences as simple and ubiquitous as daily heating and cooling by the sun (Eppes and Keanini, 2017). Cracks with orientations not readily attributable to rock anisotropies or shape of boulders or cobbles form due to tensile stresses caused by directional heating and cooling during the sun's daily transit and sporadic rains. Rock size and pavement surface age exert an influence on the development of stone cracks as the average clast size of mature desert pavements may be at or below the threshold-clast size for thermal cracking of stones.

As observed in the wall sections, the masonry stones of S1 are the smallest and their form is mostly controlled by thermal cracks. S1 was

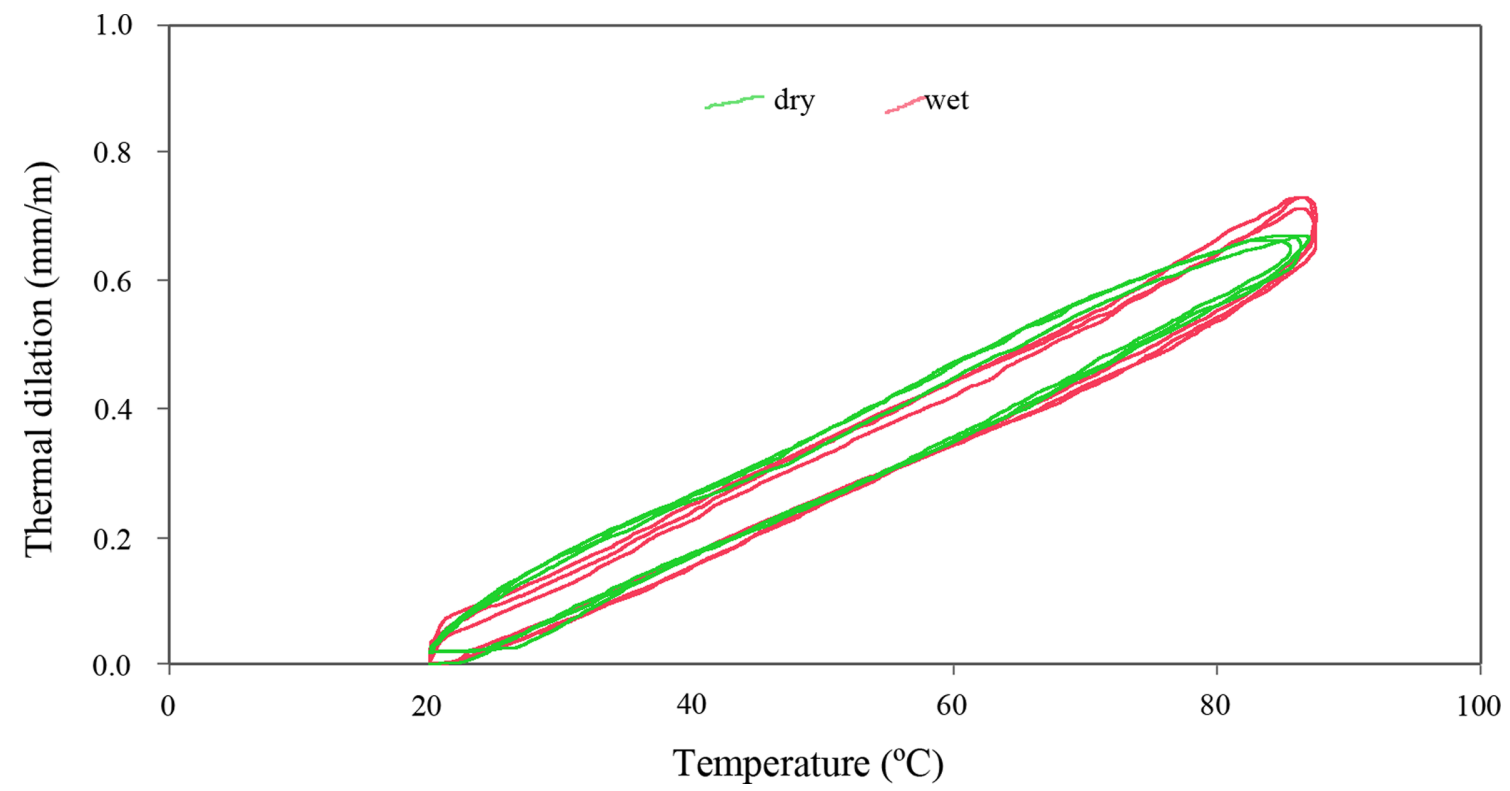

Figure 10. Thermal dilatation $\varepsilon(\mathrm{mm} / \mathrm{m})$ for three cycles as a function of temperature $\left(20-90-20{ }^{\circ} \mathrm{C}\right)$ and dry and wet conditions. 


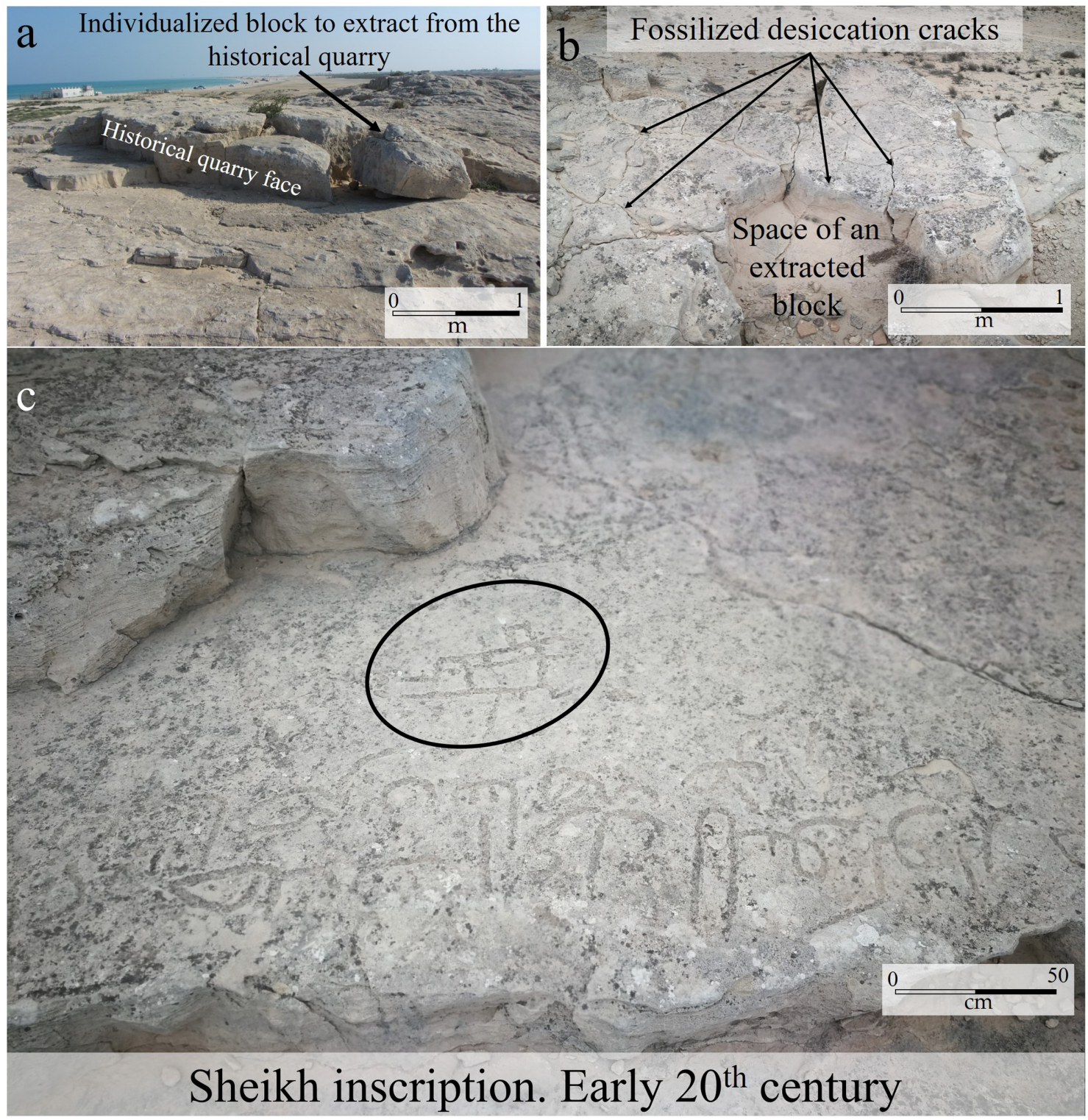

Figure 11. a-c Vestiges of historical quarries. Blocks were individualised following fossil desiccation cracks. . Sheikh's inscription, early $20^{\text {th }}$ century.

collected from the surface of the hamada, to be used mainly as filling stones in the inner cores between the masonry wall faces and wedges. They constitute approximately $15 \%$ of the masonry stones in the analysed walls.

$\mathrm{S} 2$ has greater compactness and cementation than $\mathrm{S} 3$ and $\mathrm{S} 4$ which showed the lowest values of $\mathrm{V}_{\mathrm{p}}$, due to their high macroporosity. However, S2 and S3 have high moldic porosity and they showed the highest microporosity, since many ooid nuclei are dissolved. Some of the ooids of S2 still retain the original aragonite, while others stabilised to low-Mg calcite (Holail, 2005). Quartz nuclei were observed in ooids of samples S2 and S3 with petrographic microscopy. The XRD data have not detected the presence of this mineral due to its low content. This why the characterisation of heritage stones for the location of historical quarries must be multi-analytical, with petrographic microscopy being an essential technique (Antonelli et al., 2009, 2015). It is possible that $\mathrm{S} 2$ was extracted from the top of Jebel Fuwairit fos- sil dunes, which has a wind origin and similar petrographic characteristics than S2 (Gupta and Poppelreiter, 2010). The quarrying on Jebel Fuwairit fossil dunes (Fig. 11) was facilitated by the cross-bedded strata sets in pseudohorizontal planes, along with the desiccation cracks filled with muddy material (pseudovertical planes).

Pleistocene oolites (S2 and S3) were used mainly as stretcher blocks; they constitute approximately $5 \%$ of the stones in the analysed walls.

The quarry area of Jebel Fuwairit has an inscription which shows two lines of Arabic above a complex geometric petroglyph (Fig. 11c). We interpret the inscription as a celebration of the building of a new sheikhly residence around 1900 AD by the headman of Fuwairit, Nasr bin Shahin Al-Tuwar, using stones quarried from the location of the inscription. It is one of two Arabic inscriptions in the area by sheikhs of the Tuwar family, a leading branch of the Bu Kuwara tribe, the last residents of the site. Arabic inscriptions of any date are exceptionally rare in the region (leaving aside graffiti of the second half of the $20^{\text {th }}$ 
century and later). Nasr bin Shahin had led his section of the Bu Kuwara to Fuwairit to resettle their ancestral town in the very late $19^{\text {th }}$ or first few years of the $20^{\text {th }}$ century AD. The wording of the inscription of Nasr, hadath āwal lil Būkūwāra, Nāṣr bin Shāhīn Ṭūwār translates as "a foremost event for the Bu Kuwara, Nasr Bin Shahin Tuwar", and the geometric petroglyph below it resembles a house plan. The petroglyph's outlines and proportions bear a striking resemblance to the wall outlines of a very large compound in the centre of the site (clearly visible in a 1948 aerial image).

$\mathrm{S} 3$ and $\mathrm{S} 4$ showed the highest $P e$ and MIP because these stones have abundant bio-moldic pores that can reach diameters of up to centimetres. S4 presents heterogeneity in grain size, from clay to centimeter-sized bioclasts, with high intragranular and bio-moldic porosity and it is poorly consolidated. In addition, S4 has uncemented mud, which plays a fundamental role in its deterioration because, mud leachate produces disintegration of the bioclasts. Rough and undressed masonry beachrocks (S4) constitute approximately $80 \%$ of the stones in the analysed walls. They were installed mainly as header masonry stones in the double-skinned walls following coursed random rubble masonry These masonry stones possibly come from the excavation for the foundations of the buildings.
The rubble of the archaeological site of Fuwairit shows a large amount of disaggregated bioclasts from S3 and S4 (Fig. 12), which are more susceptible to dissolution and disintegration due to their high porosity and low compactness. Therefore, $\mathrm{S} 1$ and S2 masonry stones were better preserved in the ruins and were found in greater percentage than S3 and specially S4 masonry stones, which had broken down and lost volume. This same process, although in an incipient state, can be observed in the ruins of the walls of Fig. 5 .

Characterisation of representative walls is fundamental to understanding the structural behaviour of a wall (Theodoridou and Török, 2019). Coursed rubble is the cheapest and roughest type of stone masonry. It is typically made up of stones extracted directly from the quarry with minimal efforts used to modify the corners of the stones before they are laid. Generally, the blocks of stone are irregular in shape and dimension. The courses are regular for better mechanical performance of the walls.

Materials with similar chromatic parameters should be used for possible future reconstructions. All masonry stones have undergone a colour difference between dry and wet state visible to the naked eye $\left(\Delta \mathrm{E}^{*}\right.$ values $\left.>6\right)$. $\mathrm{S} 2$ has experienced greater $\Delta \mathrm{E}^{*}$, possibly due to its high microporosity, which causes water retention in it.
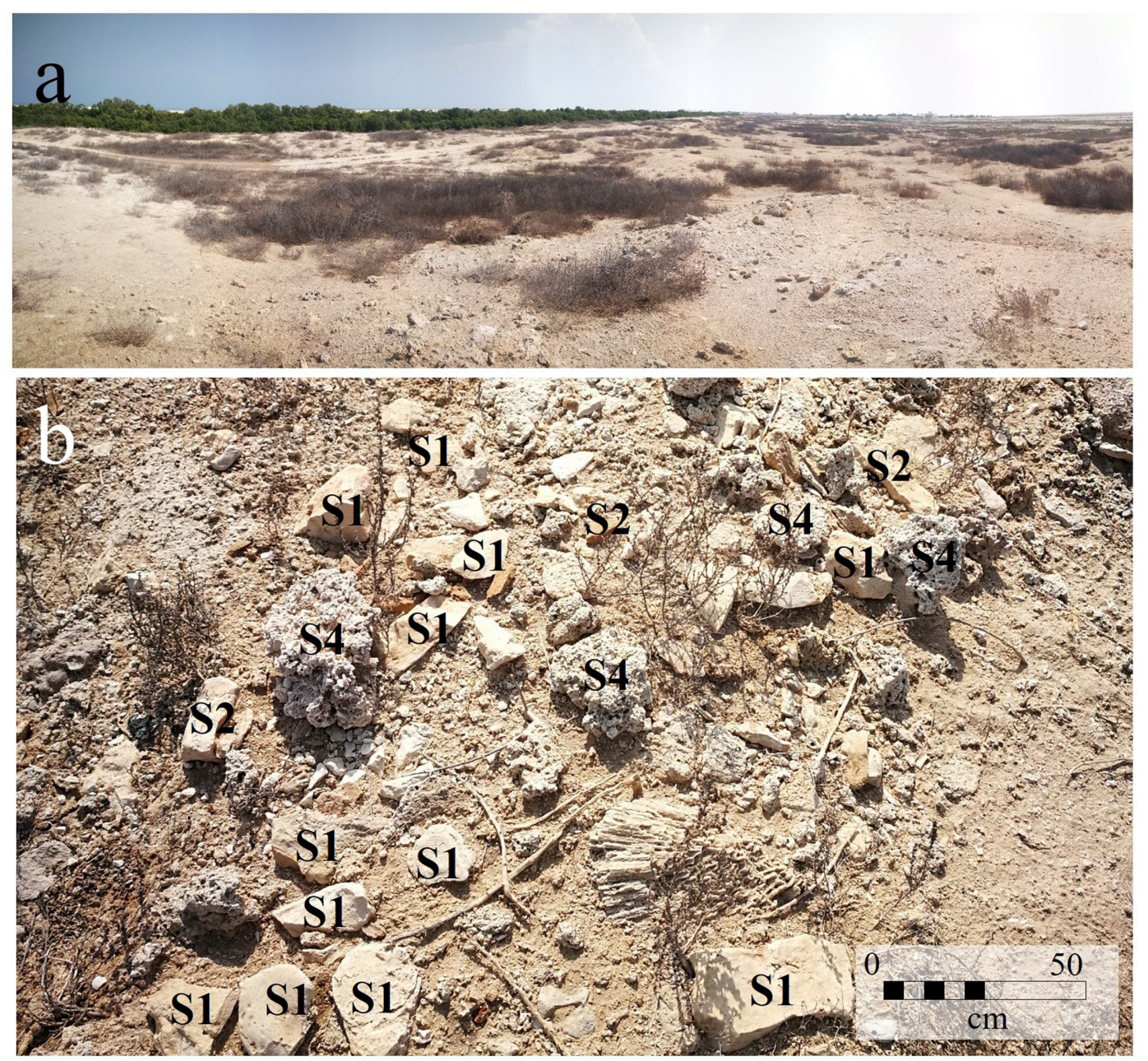

Figure 12. a. General view of the building's ruins of the Fuwairit archaeological site. b. Detail of the rubbles with the remains of the masonry stones and disaggregated masonry stone material. 


\section{Conclusions}

S1 (Umm Bab Member limestone) had low porosity and water absorption, and high bulk density and ultrasonic pulse velocity. According to its petrographic and petrophysical properties, this stone has the best quality for use as a building stone. S2 and S3 (Pleistocene oolites from Jebel Fuwairit fossil dunes) have an intermediate quality. According to the data of $P e$, water absorption, $\rho b, \mathrm{MIP}$ and $\mathrm{V}_{\mathrm{p}}$, the durability of $\mathrm{S} 2$ and S3 is lower than S1. S4 (Holocene beachrock) has the worst quality as building stones. It has low $V_{p}$, low cementation and a high percentage of mud, causing disintegration of the stone.

The sources of the building stones of Fuwairit archaeological site are in the immediate vicinity of the site, minimizing transport costs. The stones were installed directly from the source area without dressing and each type of masonry stone was used for a specific structural function within the wall.

The fact that S1 was not used as the main building stone, despite its favorable petrophysical properties, may indicate that Fuwairit's buildings were conceived to be ephemeral, prioritizing a fast and functional construction and, using the nearest and lowest quality stones as the main building material. Most Holocene masonry (S4) have disintegrated due to weathering, which caused the collapse of the building walls. The Pleistocene masonry stones (S2, S3), and especially Eocene masonry stones (S1), have conserved their size without great variation since their installation, and they have higher resistance to weathering than Holocene stones.

Rubble masonry of undressed and rough stone blocks was used for the buildings. Walls are formed by coursed random rubble masonry between two skins of walling made of unshaped stones arranged in courses of similar height.

Possible reconstruction of buildings at the archaeological site should consider that the most-used original stone was the very low quality Holocene beachrock, whose masonry stones have disintegrated with weathering. If this stone is substituted for another, the colour parameters of the replacement stone should be similar to the original one.

\section{Acknowledgements}

This study was conducted under the remit of the QNRF-funded Origins of Doha and Qatar Project, funded through the grants awarded to this project (NPRP 5-421-6-010 and the renewal, NPRP 8-1655-6064) in collaboration with Qatar Museums and Qatar Foundation. Warm personal thanks are also due to Nasr bin Shahin bin 'Isa Al-Tuwar (current head of the Al Tuwar) and Ali bin Muhammad Al-Tuwar, for their hospitality, and for sharing their family history. The Fundação para a Ciência e a Tecnologia (FCT) of Portugal supported the first author with the Stimulus of Scientific Employment, Individual Support 2017. CEECIND/03568/2017.

\section{References}

Al-Omari, A., Brunetaud, X., Beck, K., and Al-Mukhtar, M., 2019, Thermal stress and damage risk in the stones of Al-Ziggurat in Al-Nimrud city, Iraq. Journal of Cultural Heritage, v. 37, pp. 9-16. doi.org/10.1016/ j.culher.2018.10.011.

Al-Saad, H., 2005, Lithostratigraphy of the Middle Eocene Dammam Formation in Qatar, Arabian Gulf: effects of sea-level fluctuations along a tidal environment. Journal of Asian Earth Sciences, v. 25, pp. 781-789. doi.org/10.1016/j.jseaes.2004.07.009

Antonelli, F., Lazzarini, L., Cancelliere, S., and Dessandier, D., 2009, Volubilis (Meknes, Morocco): Archaeometric study of the white and coloured marbles imported in the Roman age. Journal of Cultural Heritage, v. 10, pp. 116-123. doi.org/10.1016/j.culher.2008.04.006

Antonelli, F., Lapuente, M.P., Dessandier, D., and Kamel, S., 2015, Petrographic Characterization and Provenance Determination of the Crystalline Marbles Used in the Roman City of Banasa (Morocco): New Data on the Import of Iberian Marble in Roman North Africa. Archaeometry, v. 57, pp. 405-425. doi.org/10.1111/arcm.12099

Barroso, C.E., Oliveira, D.V., and Ramos, L.F., 2018, Vernacular schist farm walls: materials, construction techniques and sustainable rebuilding solutions. Journal of Building Engineering, v. 15, pp. 334-352. doi.org/ 10.1016/j.jobe.2017.12.001

Belhaj, S., Bahi, L., and Akhssas, A., 2016, Study of Moroccan Monumental Heritage Traditional for Valorization and Conservation of Collective Memory and for Socio-eco- Tourism Sustainable Developmentcase Kasbah Chellah, Rabat. Energy Procedia, v. 97, pp. 531-538. doi.org/ 10.1016/j.egypro.2016.10.068

Cavalcante, G.H., Feary, D.A., and Burt, J.A., 2016, The influence of extreme winds on coastal oceanography and its implications for coral population connectivity in the southern Arabian Gulf. Marine Pollution Bulletin, v. 105, pp. 489-497. doi.org/10.1016/j.marpolbul.2015.10.031

Ehling, A., 2018, Cretaceous building sandstones in northern Germany. Geological Society, London, Special Publications, 486. doi.org/10.1144/ SP486.7

Eppes, M.C., and Keanini, R., 2017, Mechanical weathering and rock erosion by climate-dependent subcritical cracking. Reviews of Geophysics, 55. doi.org/10.1002/2017RG000557

Dunham, R.J., 1962, Classification of carbonate rocks according to depositional textures. American Association of Petroleum Geologists Memoir, v. 1, pp. 108-121.

Folk, R.L., 1962, Spectral Subdivision of Limestone Types. American Association of Petroleum Geologists Memoir, v. 1, pp. 62-84.

Fort, R., Alvarez de Buergo M., Perez-Monserrat E.M., Gomez-Heras M., Varas-Muriel, M.J., and Freire-Lista, D.M., 2013. Evolution in the use of natural building stone in Madrid, Spain. Quarterly Journal of Engineering Geology and Hydrogeology, v. 46, pp. 421-429. doi.org/10.1144/ qjegh2012-041

Freire-Lista, D.M., Fort, R., and Varas-Muriel, M.J., 2015, Freeze-thaw fracturing in building granites. Cold Regions Science and Technology, v. 113, pp. 40-51. doi.org/10.1016/j.conbuildmat.2017.09.049

Freire-Lista, D.M., Fort, R., and Varas-Muriel, M.J., 2016, Thermal shockinduced microcracking in building granite. Engineering Geology, v. 203, pp. 83-93. doi.org/10.1016/j.enggeo.2016.03.005

Freire-Lista, D.M., Kahraman, G., and Carter, R., 2019, Multi-analysis Characterisation of a Vernacular House in Doha (Qatar). Minerals, v. 9, pp. 241. doi.org/10.3390/min 9040241

Freire-Lista, D.M., and Fort, R., 2019, Historical City Centres and Traditional Building Stones as Heritage: the Barrio de las Letras, Madrid (Spain). Geoheritage, v. 11, pp. 71-85. doi.org/10.1007/s12371-018-0314-z

Freire-Lista, D.M., and Fort, R., 2019, Cadalso de los Vidrios leucogranite "Blanco Cristal", a widely used heritage stone. Geological Society, London, Special Publications, 486. doi.org/10.1144/SP486-2017-189

Garg, S., Kaur, P., Pandit, M., Fareeduddin, Kaur, G., Kamboj, A., and Thakur, S.N., 2019, Makrana Marble: a Popular Heritage Stone Resource from NW India. Geoheritage, Springer Berlin Heidelberg, v. 11, pp. 909-925. doi.org/10.1007/s12371-018-00343-0

Gräf, V., Jamek, M., Rohatsch, A., and Tschegg, E., 2013, Effects of thermal-heating cycle treatment on thermal expansion behavior of different 
building stones. International Journal of Rock Mechanics \& Mining Sciences, v. 64, pp. 228-235. doi.org/10.1016/j.ijrmms.2013.08.007

Grissom, C.A., Aloiz, E.M., Vicenzi, E.P., and Livingston, R.A., 2018, Seneca sandstone: a heritage stone from the USA. Geological Society, London, Special Publications, v. 486, pp. 20. doi.org/10.1144/SP486.4

Gupta, A., and Poppelreiter, M., 2010, Innovative Field Camp for Education and Industry-Academic Collaboration in Geology-Based Reservoir Model Building for Carbonate Reservoirs in the Middle East. SPE Annual Technical Conference and Exhibition. Florence, Italy, 19-22 September, 2010. doi.org/10.2118/134453-MS

Holail, H., Shaaban, M., Mansourl, A.S., and Rifai, R., 2005, Diagenesis of the Middle Eocene Upper Dammam Subformation, Qatar: Petrographic and Isotopic Evidence. Carbonates and Evaporites, v. 20, pp. 72-81. doi.org/10.1007/BF03175450

Jassim al-Kholaifi, M., 2006, Traditional architecture in Qatar. Doha: National Council for Culture, Arts and Heritage, 235 pp. ISBN: 3-9158-99921

Jin, P., Hu, Y., Shao, J., Zhao, G., Zhu, X., and Li, C., 2019, Influence of different thermal cycling treatments on the physical, mechanical and transport properties of granite. Geothermics, v. 78, pp. 118-128. doi.org/ 10.1016/j.geothermics.2018.12.00

Karagkounis, N., Latapi, B., Sayers, K., and Mulinti Sainath, R., 2016, Geology and geotechnical evaluation of Doha rock formations, Geotechnical Research, v. 3, pp. 119-136. doi.org/10.1680/jgere.16.00010

Kaur, G., Singh, S., and Kaur, P., 2019, Vindhyan Sandstone: a Crowning Glory of Architectonic Heritage from India, Geoheritage, Springer Berlin Heidelberg, pp. 1-13. doi.org/10.1007/s12371-019-00389-8

Koch, A., and Siegesmund, S., 2004, The combined effect of moisture and temperature on the anomalous expansion behaviour of marble. Environmental Geology, v. 46, pp. 350-363. doi.org/10.1007/s00254-004$1037-9$

Kravcov, A.N., and Shibaev, I.A., 2019, Measurement of Local Mechanical Characteristics of Marble by Broadband Ultrasonic Structuroscopy. International Journal of Civil Engineering and Technology, v. 10, pp. 35-42.

Leite, M.R.M., and Moura, A.C., 2013, Catalogue of Portuguese Ornamental Stones. INETI. http://rop.lneg.pt/rop/ (accessed on 19th of October 2019)

Macumber, P.G., 2011, A geomorphological and hydrological underpinning for archaeological research in northern Qatar. Proceedings of the Seminar for Arabian Studies, v. 41, pp. 187-200.

Martínez-Martínez, J., Benavente, D., Ordóñez, S., and García-del-Cura, M.A., 2008, Multivariate statistical techniques for evaluating the effects of brecciated rock fabric on ultrasonic wave propagation. International Journal of Rock Mechanics and Mining Sciences, v. 45, pp. 609-620. doi.org/10.1016/j.ijrmms.2007.07.021

Menningen, J., Siegesmund, S., Lopes, L., Martins, R., and Sousa, L., 2018, The Estremoz marbles: an updated summary on the geological, mineralogical and rock physical characteristics. Environ Earth Sci v. 77, pp. 191. doi.org/10.1007/s12665-018-7328-3

Migaszewski, Z.M., and Mader, A., 2019, The Use of Museum Collection for Studying the Origin of "Rose-Like" Calcite in the Holy Cross Mountains (South-Central Poland). Geoheritage, pp. 1-8. doi.org/10.1007/ s12371-019-00369-y

Murru, A., Freire-Lista, D.M., Fort, R., Varas-Muriel, M.J., and Meloni, P., 2018, Evaluation of Post-thermal Shock Effects in Carrara Marble and Santa Caterina di Pittinuri limestone. Construction \& Building Materials, v. 186, pp. 1200-1211. doi.org/10.1016/j.conbuildmat.2018.08.034
Peng, J., Rong, G., Tang, Z., and Sha, S., 2019, Microscopic characterization of microcrack development in marble after cyclic treatment with high temperature. Bulletin of Engineering Geology and the Environment, pp. 1-12. doi.org/10.1007/s10064-019-01494-2

Pereira, D., and Cárdenes, V., 2019, Stones and Geoheritage. Geoheritage, v. 11, pp. 1-2. doi.org/10.1007/s12371-019-00350-9

Přikryl, R., and Török, A., (eds) 2010, Natural Stone Resources for Historical Monuments. Geological Society, London, Special Publications, 333.

Rong, G., Peng, J., Yao, M., Jiang, Q., and Wong, L.N.Y., 2018, Effects of specimen size and thermal-damage on physical and mechanical behavior of a fine-grained marble. Engineering Geology, v. 232, pp. 46-55. doi.org/10.1016/j.enggeo.2017.11.011

Sadooni, F., and Al-Saad, H., 2012, Mangrove-bearing limestone from the Eocene Dammam Formation, Arabian Gulf: Implications for the mangrove dispersal controversy. Carbonates and Evaporites, v. 27, pp. 243-250. doi.org/10.1007/s13146-011-0075-0

Sanmartín, P., Silva, B., and Prieto, B., 2011, Effect of surface finish on roughness, color, and gloss of ornamental granites. Journal of Materials in Civil Engineering, v. 23, pp. 1239-1248. doi.org/10.1061/(ASCE) MT.1943-5533.0000285

Shen, Y.J., Hou, X., Yuan, J.Q., and Zhao, C.H., 2019, Experimental Study on Temperature Change and Crack Expansion of High Temperature Granite under Different Cooling Shock Treatments. Energies, v. 12, pp. 2097. doi.org/10.3390/en12112097

Siegesmund, S., and Dürrast, H., 2014, Physical and mechanical properties of rocks. In: Siegesmund S, Snethlage R (eds) Stone in architecture, 5th ed. Springer, Berlin, pp. 97-224.

Theodoridou, M., and Török, A. 2019, In situ investigation of stone heritage sites for conservation purposes: a case study of the Székesfehérvár Ruin Garden in Hungary, Progress in Earth and Planetary Science, v. 6, doi.org/10.1186/s40645-019-0268-z

Torabi-Kaveh, M., Heidari, M., Mohseni, H., and Menendez, B., 2019, Role of petrography in durability of limestone used in construction of Persepolis complex subjected to artificial accelerated ageing tests, Environmental Earth Sciences, v. 78, pp. 297. doi.org/10.1007/s12665019-8308-y

Vendrell-Saz, M., Garcia-Vallès, M., Alarcón, S., and Molera, J., 1996, Environmental impact on the Roman monuments of Tarragona, Spain. Environmental Geology, v. 27, pp. 263-269. doi.org/10.1007/BF00766696

Williams, A.H., and Walkden, G.M., 2002, Late Quaternary highstand deposits of the southern Arabian Gulf: a record of sea-level and climatic change. Geological Society of London. Special Publications, v. 1, pp. 371-386. doi.org/10.1144/GSL.SP.2002.195.01.20

Zalooli, A., Khamehchiyan, M., Nikudel, M.R., Freire-Lista, D.M., Fort, R., and Ghasemi, S., 2020, Artificial microcracking of granites subjected to salt crystallization aging test. Bulletin of Engineering Geology and the Environment. doi.org/10.1007/s10064-020-01891-y

Zoghlami, K., Martín-Martín, J.D., Gómez-Gras, D., Navarro, A., Parcerisa, D., and Rosell, J.R., 2017a, The building stone of the roman city of Dougga (Tunisia): Provenance, petrophysical characterisation and durability. Comptes Rendus Geoscience, v. 349, pp. 402-411. doi.org/10.1016/ j.crte.2017.09.017

Zoghlami, K., Lopez-Arce, P., and Zornoza-Indart, A., 2017b, Differential Stone Decay of the Spanish Tower Façade in Bizerte, Tunisia. Journal of Materials in Civil Engineering, v. 29, doi.org/10.1061/(ASCE)MT.19435533.0001774 


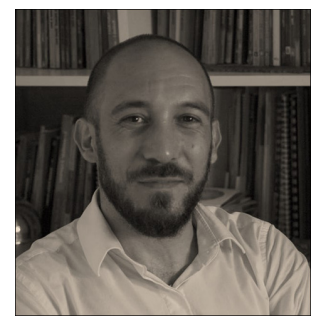

David Martín Freire-Lista holds an European $\mathrm{PhD}$ in Geology and Geological Engineering and a Master in Environmental Geology and Geological Resources. His research is mainly focused on petrophysics and decay of geomaterials. He has special interest on NonDestructive Techniques for protection, conservation and restoration of cultural heritage. He is currently working at the Centre of Geociences (CGeo-UTAD) of Portugal. He has worked at College of London University at Qatar; Geosciences Institute in Madrid, Spain, Department of Biology, Ecology and Earth Sciences, University of Calabria (Italy) and Bureau of Economic Geology (University of Texas at Austin, USA).

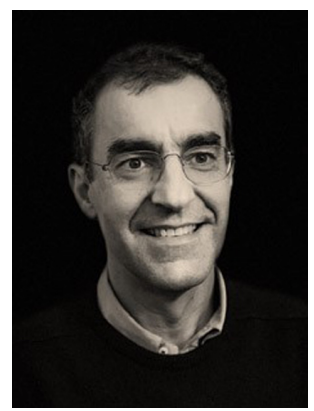

Luís Sousa works at the University of Trásos-Montes and Alto Douro (Portugal) since 1990. He holds a PhD in geology since 2001. Dr. Luís Sousa develops its scientific activity in geological resources. His research is mainly focused on building stones, namely quarrying, physical-mechanical characterisation and weathering control. He has written about 30 publications in international journals.

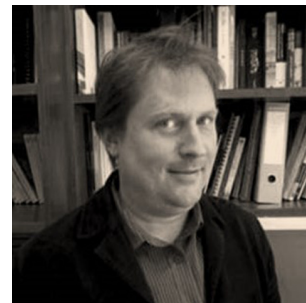

Robert Carter has long-standing interests in the archaeology and history of the Persian Gulf, with publications ranging from the first trading networks and pearl fishers of the Neolithic period, through to the historic pearl fishery in the 20th century AD. His current interests focus on the Gulf towns, and since 2012 he has investigated the people, archaeology, history, urban life and architecture of the Qatari towns in the pre-oil and early oil period, with the Origins of Doha and Qatar Project. This multidisciplinary project is funded by the Qatar National Research Fund. He is currently Visiting Professor at UCL Qatar. 